\title{
MASSIVE OPEN ONLINE COURSE (MOOC) DALAM MENINGKATKAN KOMPETENSI LITERASI INFORMASI GURU PUSTAKAWAN SEKOLAH
}

\author{
1) Riche Cynthia Johan \\ ${ }^{1}$ Dosen Departemen Kurikulum dan Teknologi Pendidikan \\ Fakultas Ilmu Pendiidkan Univeristas Pendidikan Indonesia \\ Email: riche@upi.edu
}

\begin{abstract}
Mas sive open online learning program course one form of technology -based learning is doneonline information and to support the ownership of information literacy skills for library personnel. In the school library, information literacy is the ability to produce the formof practical problem solving to find information, use the information to share information with the information and communication technology. In particular, the problems that need to be analyzed in the context of information literacy learning for school library personnel are: Firstly, how to raise awareness for actively engaged, participatory and self have information literacy ?; Second, how understanding of library information literacy includes the identification of information needs, information retrieval, information use and sharing of information through a miniature of mas sive open online learning course ?. In general, the methods used in this programis through the development of forms of learning and research on a limited scale. The next stage of knowledge transfer activities through a learning process, as signment and evaluation concludes openly and online.
\end{abstract}

Keywords: Online Learning, Literacy, Personal Library.

\section{A. PENDAHULUAN}

Ketika pemerintah menyatakan angka melek aksara lebih dari $90 \%$, pada saat yang sama minat masyarakat memanfaatkan perpustakaan masih rendah. Rendahnya intensitas kunjungan ke perpustakaan tersebut bisa pula menjadi ukuran rendahnya layanan perpustakaan dalam mengembangkan kemampuan berbagai layanannya khususnya literasi informasi. Disisi lain, tantangan pengelola perpustakaan saat ini semakin berat dan kompleks seiring dengan meningkatnya kebutuhan pengguna. Apalagi pengguna mengharapkan informasi yang dibutuhkan dapat terpenuhi secara cepat, tepat, bernilai, akurat serta efisien baik dari segi waktu maupun biaya. Itulah yang akhirnya menjadi alasan bahwa perpustakaan yang baik dapat diukur dari keberhasilan pustakawannya dalam menyajikan pelayanan yang bermutu kepada penggunanya.

Ada suatu pendapat bahwa "Library is Librarian" (perpustakaan adalah pustakawan). Pendapat ini mengandung pengertian bahwa sebuah perpustakaan bukan lagi hanya merupakan tempat atau aspek fisik saja, tetapi lebih merupakan segenap aktivitas yang dimotori oleh pustakawannya. Dengan demikian, pustakawan merupakan salah satu sumber daya yang menggerakkan sumber daya yang lain dalam organisasi perpustakaan yang memungkinkan perpustakaan dapat berperan secara optimal dalam melaksanakan tugas pokok dan fungsinya.

Meluasnya sumber dan akses informasi dewasa ini menuntut tenaga pengelola perpustakaan sekolah untuk mengembangkan profesionalisme dan kompetensinya, karena kebutuhan informasi dan pengetahuan siswa semakin cepat dan luas. Selain menyediakan sumber dan akses informasi, pengelola perpustakaan dituntut untuk mampu bekerja sama dengan guru, staf dan komite sekolah dalam usaha mengimplementasikan kurikulum dengan memanfaatkan sumber-sumber informasi di perpustakaan untuk menunjang keberhasilan studi dan pengembangan karir siswa di kemudian hari.

Siswa dan guru pada generasi sekarang sudah memiliki kebutuhan untuk mendapatkan informasi cepat dan akurat, dengan berkembangnya digital gadgets 
dengan harga yang sangat murah berkisar 100-500 ribu saat sekarang sudah bisa mendapatkan modem atau untuk terkoneksi dengan internet, belum lagi dengan handphone yang menawarkan fasilitas browsing dan jejaring sosial yang berkisar pada harga 500 ribu sampai 1 juta, ini juga berkorelasi dengan penyediaan pulsa atau biaya koneksi internet yang sama-sama menawarkan ragam provider dengan ragam pilihan harga, berkisar 2-10 ribu per satu hari atau 30-100 ribu rupiah per bulan kita dapat menjelajah dunia maya dengan mudah dan cepat.

Bila kemudahan dan kecepatan akses juga tidak ditunjang dengan kemudahan dan kesanggupan dalam memanfatkannya akan sangat disayangkan, berimbas pada tenaga pengelola perpustakaan yang kompetensinya juga sudah semakin meluas kepada kemampuan literasi informasi. Tercermin dalam PERMEN No 25 tahun 2008 dalam dimensi kompetensi pendidikannya seorang tenaga pengelola perpustakaan memiliki tugas untuk melakukan bimbingan literasi informasi bagi seluruh warga belajar di sekolah. Keahlian literasi informasi mencakup kemampuan untuk mengetahui kapan informasi dibutuhkan dan mengidentifikasi informasi yang dibutuhkan serta sumbersumbernya; menempatkan dan mengakses informasi secara efektif dan efisien mengevaluasi informasi secara kritis menata dan menggabungkan informasi ke dalam pengetahuan menggunakan informasi secara legal dan etis serta mengkomunikasikan informasi tersebut.

Hal tersebut memperlihatkan bahwa pengelola perpustakaan sekolah harus mempunyai komitmen dengan penuh kesadaran agar dapat mengakses, memahami dan memanfaatkan informasi yang diperoleh untuk dikomunikasikan kepada masyarakat yang membutuhkan. Namun demikian terdapat hambatanhambatan yang dimiliki oleh pengelola perpustakaan sekolah dalam menguasai kemampuan literasi informasi tersebut adalah yang pertama; para pengelola perpustakaan sekolah adalah guru yang juga mengajar suatu materi pembelajaran dengan beban mengajar yang kurang memenuhi, tercantum dalam UU 14/ 2005/ Pasal 35 ayat 1 dan 2, sekurang-kurangnya 24 jam tatap muka dalam satu minggu, mencakup kegiatan pokok merencanakan pembelajaran, melaksanakan pembelajaran, menilai hasil pembelajaran, membimbing dan melatih peserta didik. Sedangkan bagi pengelola perpustakaan itu perlu menyelesaikan 12 jampel di kelas dan 12 jampel untuk melakukan tugas di perpustakaan, artinya pekerjaan yang harus diselesaikan setiap harinya oleh pengelola perpustakaan sekolah akan mengakibatkan kurangnya kesempatan untuk menempuh pendidikan dan pembelajaran yang pada akhirnya menjadi kendala untuk menghadiri kegiatan pembelajaran.

Selanjutnya hambatan latar belakang pendidikan yang bukan diploma atau sarjana perpustakaan akan memberikan kesan bahwa pengelola perpustakaan kurang kompeten dalam menyediakan layananan di perpustakaan sekolah, disudut pandang ini banyak kebutuhan dari pengelola perpustakaan untuk mengembangkan diri dan memenuhi tuntutan PERMEN No 25 tahun 2008 tersebut, dengan upaya berlatih dan membina diri tanpa banyak beranjak dari tempat bekerja dan biaya yang cukup besar.

Tantangan dari perkembangan teknologi informasi dan komunikasi sudah tidak dapat ditawar dan dirasakan imbasnya pada persekolahan khususnya pada berbagai pengembangan keilmuan yang harus dipelajari oleh siswa menjadi pengetahuan dan pengalaman yang bermakna yang akan dimiliki, tentu menjadi sangat perlu diperhatikan oleh pihak sekolah untuk dapat bersama-sama memberikan layanan literasi informasi. Penguatan kemampuan tersebut perlu 
dibangun bersama-sama dengan kesepakatan dan kesepahaman dari berbagai pihak, Universitas Pendidikan Indonesia yang juga memiliki Program Studi Perpustakaan dan Infromasi (tahun 1980an passing out dan dibuka kembali 2009) yang lebih kental dengan kependidikan dan pengasuhan keilmuan perpustakaan akan sangat memiliki peranan yang strategis untuk dapat majukan perkembangan keilmuan perpustakaan.

Universitas Pendidikan Indonesia dengan tenaga ahli ilmu perpustakaan di Perpustakaan pusat dan Fakultas Ilmu Pendidikan perlu tanggap dalam memberi warna dan wawasan yang lebih dalam menjawab tantangan yang ada di persekolahan dalam memberikan pelayanan dan bimbingan di perpustakaan sekolah, sehingga rendahnya angka partisipasi guru, siswa dan pengelola perpustakaan sekolah dalam pemanfaatan perpustakaan sekolah dapat diatasi. Bahkan lebih luas lagi menjadi percontohan universitas yang mampu memberikan pembinaan dalam skala besar dan murah kepada para pengelola perpustakaan dengan biaya awal yang tidak terlalu besar namun kedepan hal ini menjadi penguatan kapasitas insitusi dan memberikan benefit kepada institusi, tentu dengan pengelolaan yang serius dan pemeliharaan sistem yang kontinu.

Pemikiran-pemikiran tersebut diatas ditelaah lebih dalam melalui kajian penelitian ini, pembinaan literasi informasi dengan bentuk pembelajaran massive open online courses bagi pengelola perpustakaan sekolah diharapkan akan memberikan jawaban dalam mengatasi salah satu kendala dan tantangan yang ada tersebut, dimana program ini memberikan kesempatan besar bagi para pengelola perpustakaan sekolah untuk mengembangkan kompetensi dalam literasi informasi dengan sistem pembelajaran online.

\section{B. KAJIAN LITERATUR}

Merujuk pada analisis kondisi yang telah dilakukan, tergambar bahwa sebenarnya ditemukan kebutuhan dari para guru pengelola perpustakaan untuk mengembangkan salah satu potensi penunjang kemampuan guru pustakawan sesuai dengan Permen 25 Tahun 2008 pada kompetensi kependidikan, serta kemampuan yang harus dibangun dalam pendidikan abad 21 yaitu salah satunya adalah kompetensi literasi informasi.

Kemampuan ini dalam penelaahan dokumentasi peneliti masih rendah ditemukan pada tenaga pendidik maupun kependidikan di sekolah, bahkan di bawah prosentasi yang ada di negara berkembang lainnya. Para pengelola perpustakaan umumnya masih sangat disibukkan dengan administrasi pengelolaan mata pelajaran yang juga harus diembannya disamping tugas tambahannya sebagai guru pustakawan atau pengelola perpustakaan.

Para pengelola perpustakaan yang pada dasarnya guru tersebut masih berorientasi bahwa mereka yang kebanyakan bukan dari tenaga pustakawan yang berijasah $\mathrm{S} 1$ hanya bisa mengembangkan perpustakaan berdasarkan koleksi yang dimiliki artinya masih sangat mengandalkan adanya sarana prasarananya di perpustakaan. Para pengelola perpustakaan juga masih merasa kesulitan untuk mengikuti kegiatan pembinaan yang memerlukan kehadiran mereka dalam suatu tempat dan waktu yang sangat ketat.

Kebutuhan pemerataan dalam skill pengelolaan informasi disekolah sangat dibutuhkan tentu saja oleh seluruh komponen sivitas sekolah, para pengelola perpustakaan dihadapkan pada tantangan teknologi dan informasi yang berkembang pesat sehingga dirasakan adannya kebutuhan untuk mendeteksi informasi, menelusur dan menggunakan informasi tersebut untuk pemecahan masalah 
pembelajaran.

Atas dasar itulah maka diperlukan suatu program pembinaan kepada para pengelola perpustakaan tentang kesadaran dalam pemilikian kemampuan konsep literasi informasi (soft skill) dan juga kemampuan dalam keterampilan mengelola informasi sampai membagikannya kembali (hard skill) untuk pemecahan masalah pembelajaran. Sehingga yang menjadi permasalahan utama yang dirasakan oleh para pengelola perpustakaan sebagai khalayak sarasan adalah "Bagaimana mengembangkan kemampuan literasi informasi bagi tenaga pengelola perpustakaan untuk meningkatkan kemampuan menyelesaikan permasalahan pembelajaran sebagai bentuk solusi dan pemberdayaan perpustakaan sebagai sumber daya pembelajaran di sekolah?" Secara spesifik permasalahan dalam memenuhi kemampuan literasi informasi untuk pengelola perpustakaan diuraikan sebagai berikut.

1. Bagaimana menumbuhkan kesadaran untuk berperan aktif, partisipatif dan mandiri yang memiliki literasi informasi?

2. Bagaimana pemahaman literasi informasi perpustakaan meliputi identifikasi kebutuhan informasi, pencarian informasi, penggunaan informasi dan berbagi informasi melalui bentuk mini dari pembelajaran massive open online course?

Permasalahan-permasalahan tersebut yang menjadi dasar untuk dikembangkannya model pembinaan literasi informasi dalam bentuk fleksibel namun sangat membantu dalam pemahaman soft skill dan hardskill pengelola perpustakaan.

\section{METODE PENELITIAN \\ 1. Literasi}

Kata literacy (Inggris) nampaknya

lebih popular disebut di Indonesia "literasi" saat ini. Kata literacy itu sendiri sebenarnya datang dari bahasa Latin, littera yang kemudian dipakai orang Inggris untuk kata letter dan dengan demikian sebenarnya memang berurusan dengan aksara atau tulisan. Sewaktu kata literacy digunakan oleh orang-orang Inggris pertama kali di tahun 1883, yang dimaksud adalah kemampuan membaca dan menulis sebagai hasil dari pendidikan formal. Sejak itu pula, kata literasi menjadi sebuah capaian, luaran, atau bahkan prestasi dari sebuah sistem pendidikan yang baku dalam hal menulis dan membaca.

Pada bidang perpustakaan, tentunya kita mengenal literasi informasi, literasi media, dan yang terbaru literasi informasi dan media. Badan internasional seperti UNESCO membuat definisi-definisi berikut ini:

Information and media literacy enables people to interpret and make informed judgments as users of information and media, as well as to become skillful creators and producers of information and media messages in their own right.

Information literacy enables people to interpret and make informed judgments as users of information sources, as well as to become producers of information in their own right. Information literate people are able to access information about their health, their environment, their education and work, empowering them to make critical decisions about their lives, e.g. in taking more responsibility for their own health and education In a digital world, information literacy requires users to have the skills to use information and communication technologies and their applications to access and create information. For example, the ability to navigate in cyberspace and negotiate 
hypertext multimedia documents requires both the technical skills to use the Internet as well as the literacy skills to interpret the information.

Semua literasi di atas sebenarnya adalah sebuah capaian setelah orang menguasai sesuatu yang mendasar terlebih dahulu, yakni literasi dalam pengertian dasarnya sebagai kemampuan baca tulis. Namun istilah-istilah itu memang terkadang sekaligus membingungkan, sehingga orang ingin kembali mendapat kepastian, apa yang sesungguhnya dimaksud dengan literasi. Dengan demikian ahli-ahli membatasi literasi pada membaca dan menulis, definisi di atas malah memperluasnya menjadi kemampuan berbahasa, melibatkan tak hanya tulisan tetap juga berbicara, mendengar, dan berpikir kritis. Hal ini sebenarnya tidak mengherankan dan memperlihatkan betapa evolusi konsep literasi sudah berlangsung lama, sekaligus juga memperlihatkan semakin kompleks dan relevannya literasi untuk kehidupan masa kini.

\section{Literasi dan Teknologi Informasi}

(...) writing (and especially alphabetic writing) is a technology, calling for the use of tools and other equipment (...). It initiated what print and computers only continue, the reduction of dynamic sound to quiescent space, the separation of the world from the living present, where alone spoken words can exist.

(Ong, 2002 : 80)

Kutipan dari Ong tersebut di atas mengingatkan kepada kita bahwa literasi mengandung dimensi teknologi, mulai dari codex yang dianggap "nenek moyang" buku, sampai teknologi digital masa kini. Juga jelaslah bahwa bahasa tulisanlah yang dalam jargon Ong, pertama kali "menteknologikan kata-kata" (the technologizing of the word). Sebelum masa Internet dan digitalisasi besarbesaran, teknologi yang paling dianggap "bertanggungjawab" terhadap perkembangan literasi tentunya adalah mesin cetak dan berbagai penelitian telah menemukan banyak bukti bahwa teknologi cetak ikut menentukan bentuk literasi di sebuah masyarakat. Perkembangan teknologi selanjutnya, yakni teknologi elektronik, juga mendapat tempat dalam perkembangan literasi.

Sebagian besar perhatian tentang kaitan antara teknologi dan literasi saat ini terfokus pada peluang penggunaan perangkat digital untuk komunikasi dan representasi, termasuk bagaimana Internet dan keragaman teknologi memengaruhi perkembangan literasi, baik dari sisi konsumen maupun produsen teks. Pihak yang seharusnya paling segera melihat peluang maupun ancaman dari teknologi informasi terhadap pengembangan literasi adalah pengambil kebijakan dan penyelenggara pendidikan, khususnya guru-guru bahasa. Dari kepedulian pihak inilah antara lain muncul pemikiran tentang the new literacy yang biasanya dikaitkan dengan penggunaan suratelektronik, computer games, digital personal assistants, digital storytelling, mobile phones, video digital, akses ke Internet, chat rooms, wikis, blogs, iPods, dan perangkat permainan lainnya. Penggunaan perangkat-perangkat ini memerlukan keterampilan-keterampilan khusus/baru, yang tidak hanya melibatkan cara memahami teksn permain tertulis tetapi juga cara memanipulasi dan memahami makna dari penggunaan berbagai simbol visual maupun bunyi (Lankshear dan Knobel, 2003; Carrington, 2004).

Ketersediaan berbagai gadgets berbasis digital, terutama untuk generasi masa kini, menciptakan lanskap yang kaya media (rich media landscape) sehingga anak-anak dan remaja memerlukan pula keterampilan sosial baru agar dapat secara 
efetif terlibat dalam kolaborasi menggunakan jejaring sosial di Internet. Keterampilan baru ini tetap bertumpu pada literasi "tradisional" tetapi ditambah dengan keterampilan teknis dan kemampuan analisis kritis. Untuk itu sekolah dan perpustakaanpun perlu mengenal berbagai bentuk sarana dan aktivitas literasi menggunakan perangkat digital, seperti petunjukan sambil bermain, simulasi, menyelesaikan tugas-tugas secara multitasking, dan sebagainya.

New Literacies yang dialami siswa di luar sekolah, terutama di rumah dan dengan sesama teman sepermainan, seringkali merupakan proses pembelajaran yang lebih mendalam dan lebih kaya daripada pembelajaran yang mereka peroleh di sekolah. Anak-anak seringkali mampu mengembangkan sendiri keterampilan, strategi, dan insights yang mereka butuhkan untuk secara sukses memanfaatkan Teknologi Informasi dan Komunikasi (TIK) yang terus berubah.

\section{Literasi Informasi dan Lite rasi Media di Perpustakaan}

"The changing media landscape and the rapid growth in information are affecting individuals and societies now more than ever. In order to succeed in this environment, and to resolve problems effectively in every facet of life, individuals, communities and nations should obtain a critical set of competencies to be able to seek, critically evaluate and create new information and knowledge in different forms using existing tools, and share these through various channels."

(IFLA , 2012)

Bruce (1997) mensinyalir, pemikiran tentang literasi informasi muncul bersamaan dengan kemunculan konsep masyarakat informasi. Sebagai sebuah konsep yang jelas dan baku, literasi informasi baru muncul dalam publikasi final report American Library Association tahun 1989, dan sejak itulah konsep literasi informasi mulai digunakan secara meluas. Namun Bruce juga mengatakan bahwa keinginan untuk menggunakan istilah literasi informasi sudah ada di kalangan pustakawan sejak lama sebelumnya, yaitu sejak para pustakawan berketetapan untuk mempertegas peran mereka dalam pendidikan yang mereka perjuangkan sejak tahun 1960an. Sejak 1990an konsep literasi informasi tak hanya diperbincangkan tetapi sudah diterapkan menjadi berbagai model dan aktivitas, baik di pendidikan tingkat dasar, menengah, dan terlebih-lebih di pendidikan tinggi.

Hobbs (2011), dengan latarbelakang dan motivasi berbeda juga menganjurkan agar para pustakawan sekolah mulai dengan serius mengupayakan literasi media, antara lain untuk membantu peserta didik menghadapi apa yang disebut "digital risk" sehingga dapat menghindari beberapa ancaman dari situasi sehari-hari yang sudah begitu terpapar oleh beragam media massa, budaya popular, dan media digital. Menurutnya, selain melengkapi sekolah dengan perangkat TIK mutakhir, "School librarians, teachers, and educational technology leaders can help shift the focus to emphasize how digital tools are used to promote critical thinking, creativity, and communicationand collaboration skills".

Secara keseluruhan, pada akhirnya memang harus ada peninjauan tentang apa yang sesungguhnya kita inginkan dengan literasi media. Sebagaimana Potter (2010) mengatakan, saat ini ada tiga pertanyaan yang harus dijawab: (1) What are the media? - haruslah jelas apakah akan memfokuskan pada satu medium saja (misalnya televisi atau komputer saja), atakah beberapa media saja, atau secara umum dan menyeluruh. (2). What do we mean by literacies? - apakah maksudnya peningkatan dalam keterampilan menggunakan/ media, ataukah meningkatkan pengetahuan dan 
pemahaman, ataukah semuanya? (3). What should be the purpose of media literacy? sebagian menjawab dengan tujuan normatif kualitatif, yaitu untuk meningkatkan kualitas hidup individu, khususnya dengan memberdayakan mereka dalam mengendalikan media; sementara ada yang hanya spesifik menargetkan literasi media untuk tujuan pendidikan dan membantu anak didik menyelesaikan pendidikannya.

\section{Massive Open Online Courses}

\section{Massive Open Online Courses} (MOOC) adalah sebuah model pembelajaran atau pembelajaran yang dapat dilakukan secara online untuk skala besar dan jumlah partisipan banyak tersebar dari beberapa wilayah yang berlainan dan berjauhan. Pelaksanaan kegiatan pembelajaran model MOOC ini biasa dilakukan melalui web yang dapat diakses dengan jaringan internet. Dengan demikian terdapat dua karakteristik model MOOC yaitu; (1) Pemanfaatan jaringan internet dan web sebagai sarana dalam kegiatan pembelajaran jarak jauh. (2) Adanya jumlah peserta banyak dan skala pembelajaran yang besar.

Pada pengembangan program pembelajaran model MOOC ini, dibagi menjadi enam langkah pengembangan :

a. Task Definition, pada langkah pertama dalam peserta pembelajaran diajarkan untuk memiliki kemampuan dalam menjabarkan apa yang harus dilakukannya kedalam bentuk deskriptif, terstruktur maupun pointer pekerjaan yang harus dikerjakannya.

b. Information Seeking Strategies, langkah selanjutnya peserta pembelajaran diberikan bekal untuk menciptakan alternatif-alternatif strategi dalam mendapatkan informasi yang dibutuhkan dalam hal tersebut. c. Location and Access, pada langkah ini peserta pembelajaran diarahkan untuk memiliki kemampuan dalam menemukan sumber dari informasi apa yang sedang mereka butuhkan.

d. Use of Information, setelah diketahui sumber informasi yang akan mereka dapatkan, peserta pembelajaran diberikan bekal untuk memiliki kemampuan dalam menggunakan informasi tersebut sehingga dapat bermanfaat bagi khalayak.

e. Synthesis, tahap syhthesis ini merupakan tahapan yang mengajarkan peserta pembelajaran dalam mengembangkan cara untuk mengakhiri sebuah permasalahan.

f. Evaluation, tahapan evaluasi ini untuk memberikan ukuran kepada peserta pembelajaran "bagaimana" membuat sebuah keputusan dan menilai berhasil atau tidaknya, baik atau tidak baiknya sebuah program yang dikembangkan.

\section{HASIL DAN PEMB AHASAN}

Pengembangan program pembelajaran $M O O C$ diperuntukan tenaga pengelola perpustakaan sekolah sebagai objek penelitian. Selanjutnya pihak-pihak terkait sebagai pendukung (suporting system) dalam penelitian ini meliputi: Dosen UPI sebagai penyelenggara sekaligus sebagai fasilator dalam kegiatan pembelajaran, Kepala sekolah sebagai pemberi ijin dan penentu dalam keikutsertaan dari pengelola perpustakaan sekolah dalam proses pembinaan program, serta praktisi pengembang sistem open online courses yang ada di lapangan.

Adapun pengelola perpustakaan sebagai sasaran pengembangan pembelajaran, memiliki karakeristik sebagai berikut, bertugas sebagai kepala perpustakaan dan staf pengelola perpustakaan yang memiliki integritas tinggi dalam memajukan perpustakaan 
sekolah, pengelola perpustakaan sekolah dengan masa kerja lebih dari satu tahun dalam mengelola perpustakaan di sekolah dibuktikan dengan SK Penugasan di Perpustakaan sekolah. Peserta yang memiliki komitmen yang tinggi untuk ikut dalam program ini, lebih jauh lagi adalah memiliki keinginan kuat untuk maju berkembang menjadi pengelola perpustakaan yang melek informasi. Memiliki kemampuan awal (entry behaviour level) yang cukup baik, hal tersebut sangat diprioritaskan demi terwujudnya kesinambungan program pembelajaran yang menuntut kemampuan belajar mandiri, disiplin waktu serta membutuhkan kemampuan praktis dalam berteknologi informasi dan komunikasi.

Secara rinci hasil pertama dalam kegiatan penelitian ini adalah kesadaran pengelola perpustakaan (softskill) untuk berperan secara aktif, partisipatif dan mandiri dalam pemilikan literasi informasi dibangkitkan melalui partisipasi aktif dari mereka untuk mengembangkan diri melalui kegiatan pembelajaran. Penawaran untuk mengikui pembelajaran melalui penyebaran informasi yang cepat dan luas yang dilakukan di tiga wilayah sampel yaitu kota Bandung, Kabupaten Bandung dan Kota Cimahi. Hampir setiap wilayah itu pepustakaan sekolahnya diberi kesempatan untuk mengikuti bentuk tawaran pembelajaran yang menggunakan teknologi informasi dan komunikasi, diakses dengan waktu yang fleksibel dan dilakukan di tempat mereka bekerja dan tidak dipungut biaya namun memberikan nilai tambah pengetahuan yang cukup banyak.

Pemahaman tenaga pengelola perpustakaan tentang literasi informasi yang meliputi identifikasi kebutuhan informasi, penelusuran informasi, pengemasan infomasi dan pembagian informasi juga dikembangkan melalui pemberian konsep dan pekerjaan praktis dalam pembelajaran yang bersifat online.
Keterampilan-keterampilan praktis (hardskill) literasi informasi yaitu menyusun dan mengemas informasi berbasis teknologi informasi dan komunikasi sebagai bentuk layanan di perpustakaan terlatih dalam kemasan pembelajaran bentuk mini dari MOOC, sebab bila itu diberlakukan dalam bentuk yang sebenarnya, hal ini membutuhkan pengadaan sistem yang terintegrasi dan tidak dapat dilakukan oleh hanya sebagian orang yang terkait penelitian, namun dukungan sumber daya universitas atau lembaga tertentu yang akan memperkuat seluruh tahapan kegiatan.

Melalui pendekatan pembelajaran yang dikemas dalam pembelajaran online sebagai bentuk mini dari program $M O O C$, yaitu mulai dari 1) menyiapkan kemampuan dalam menjabarkan apa yang harus dilakukannya kedalam bentuk deskriptif, terstruktur maupun pointer pekerjaan yang harus dikerjakannya. 2) diberikan bekal untuk menciptakan alternatif-alternatif strategi dalam mendapatkan informasi yang dibutuhkan dalam hal tersebut. 3) memiliki kemampuan dalam menemukan sumber dari informasi apa yang sedang mereka butuhkan. 4) setelah diketahui sumber informasi yang akan mereka dapatkan, peserta pembelajaran diberikan bekal untuk memiliki kemampuan dalam menggunakan informasi tersebut sehingga dapat bermanfaat bagi khalayak. 5) tahapan mengembangkan cara untuk mengakhiri sebuah permasalahan. 6) tahapan evaluasi ini untuk memberikan ukuran kepada peserta pembelajaran "bagaimana" membuat sebuah keputusan dan menilai berhasil atau tidaknya, baik atau tidak baiknya sebuah program yang dikembangkan.

$$
\text { Pengembangan kompetensi }
$$

diarahkan pada pemenuhan kemampuan soft skill dan hard skill tentang literasi informasi. Program pembinaan literasi informasi ini telah menghasilkan luaran 
(output) berupa diperolehnya pengetahuan dan keterampilan praktis bagi pengelola perpustakaan dalam hal pengembangan jasa layanan infomasi dalam pembelajaran disekolah.

Secara umum pengembangan MOOC telah dilaksanakan dan kelengkapan pembelajaran telah selesai disiapkan yang meliputi: kurikulum pembelajaran, panduan teknis pembelajaran, jadwal pembelajaran, materi pembelajaran, video pembelajaran, web pembelajaran yang dapat di akses dalam http://risettekpen.org dimana grasi dalam web prodi perpustakaan http://pspi.upi.edu.

Jumlah keseluruhan yang

mendaftar untuk mengikuti kegiatan pembelajaran dalam bentuk $M O O C$ yaitu 40 orang, namun dalam pelaksanaan kegiatan pembelajaran yang terekam menyelesaikan kegiatan pembelajaran adalah sebanyak 28 orang sampai dengan tuntas (proses akhir pembelajaran yaitu tahapan evaluasi). Berikut pengolahan hasil belajar $y$ ang memberikan pemahaman tentang ketercapaian kemampuan literasi informasi.

pembelajaran ini akan terinte

Tabel 1. Deskripsi Hasil Belajar

\begin{tabular}{|l|r|r|r|r|r|}
\hline & \multicolumn{1}{|c|}{$\mathrm{N}$} & \multicolumn{1}{c|}{ Mean } & Std. Deviation & Minimum & \multicolumn{1}{c|}{ Maximum } \\
\hline Hasil_Pre & 28 & 53.4821 & 7.54122 & 37.50 & 73.75 \\
\hline Hasil_Post & 28 & 62.9107 & 10.98825 & 43.00 & 91.00 \\
\hline
\end{tabular}

Peserta pembelajaran MOOC menunjukan keseriusan dalam proses pembelajaran secara online dari mulai kegiatan awal baik dalam pre test, tes formatif, latihan dan post test. Hasil pre test sebesar rata-rata sebesar 53.48, peningkatan nilai akhir yang diperoleh peserta pembelajaran hasil post test yang menunjukan rata-rata nilai sebesar 62.91, hal ini menunjukan adanya peningkatan hasil belajar peserta pembelajaran yang terlihat meningkat dari rata-rata nilai pre test yang dilakukan sebelumnya, namun ngan uji hipotesis menggunakan uji parametrik atau non parametrik. hal ini belum bisa dijadikan sebagai penarikan kesimpulan bahwa model pembelajaran online ini dikatakan efektif. Untuk mengetahui efektifitasnya harus dibuktikan dengan pengujian perbedaan kedua rata-rata tersebut.

Sebelum melakukan perhitungan uji perbedaan hasil tes pada tahap ujicoba terbatas yang disebabkan oleh pemberian perlakuan dengan membandingkan skor pretes dan postes, maka terlebih dahulu dilakukan pengujian normalitas datanya. Hal itu akan menentukan perhitu

Tabel 2. Uji Normalitas Data

One-Sample Kolmogorov-Smirnov Test

\begin{tabular}{|c|c|c|c|}
\hline & & Hasil Pre Test & Hasil Post Test \\
\hline \multicolumn{2}{|l|}{$\mathrm{N}$} & 28 & 28 \\
\hline \multirow[t]{2}{*}{ Normal Parameters $^{\mathrm{a}}$} & Mean & 53.4821 & 62.9107 \\
\hline & Std. Deviation & 7.54122 & 10.98825 \\
\hline \multirow[t]{3}{*}{ Most Extreme Differences } & Absolute & .159 & .124 \\
\hline & Positive & .159 & .124 \\
\hline & Negative & -.133 & -.111 \\
\hline
\end{tabular}




\begin{tabular}{|l|r|r|}
\hline Kolmogorov-SmirnovZ & .841 & .654 \\
\hline Asymp.Sig.(2-tailed) & .479 & .785 \\
\hline
\end{tabular}

a. Test distribution is Normal.

Dari tabel di atas dapat dilihat bahwa uji Kolmogorov-Smirnov untuk pre test dan post test berturut-turut sebesar 0.479 dan 0.785. Dari kedua data tersebut nilainya lebih besar daripada taraf nyata 0.05 . Dengan demikian, dapat disimpulkan bahwa hasil pre test dan post test berasal dari populasi yang berdistribusi normal.

\begin{tabular}{lcr}
\multicolumn{1}{c}{ Kemudian } & untuk & mengetahui \\
homogenitasnya & dilakukan & pengujian \\
homogenitas & varians & dengan \\
membandingkan hasil pre test & dan post test \\
menggunakan uji levene, hasil yang \\
diperoleh & sebagai & berikut
\end{tabular}

Tabel 3

Hasil Uji Homogenitas Data

\begin{tabular}{|c|c|c|c|c|}
\hline \multicolumn{7}{|c|}{ Uji Homogenitas Varians } \\
\hline Nama Tes & $\begin{array}{c}\text { Levene } \\
\text { Statistic }\end{array}$ & df1 & df2 & Sig. \\
\hline Uji MOOC & 3.530 & 1 & 54 & 0.066 \\
\hline
\end{tabular}

Dari tabel di atas tampak bahwa nilai signifikansi uji levene pada hasil pre test dan post test diperoleh nilai sebesar 0.066 nilai signifikansi tersebut lebih besar daripada taraf nyata 0.05 . Dengan demikian, dapat disimpulkan bahwa hasil tes yang diberikan berasal dari populasi yang memiliki varians yang sama, atau dengan kata lain varians yang dimiliki oleh hasil pre test dan post test bersifat homogen. Dari uraian di atas dapat disimpulkan bahwa data hasil tes dalam sebagai berikut. penelitian ini memiliki distribusi yang bersifat normal dan varians yang homogen. Dengan demikian, data tersebut telah memenuhi syarat untuk dianalisis lebih lanjut, yakni untuk menguji kebermaknaannya atau peningkatannya.

Data hasil tes masing-masing dianalisis dan diuji perbedaannya dengan uji t. Pengujian uji $\mathrm{t}$ sampel dependen terhadap masing-masing pre test dan post test yang diperoleh dari hasil penelitian

Tabel 4

Uji t Sampel Berpasangan

\begin{tabular}{|c|c|c|c|}
\hline & t & df & Sig. (2-tailed) \\
\hline Uji beda $M O O C$ & 3.614 & 27 & 0.005 \\
\hline
\end{tabular}

Berdasarkan hasil perhitungan seperti terlihat pada tabel di atas, maka $\mathrm{t}$ hitung adalah 3.614 dengan probabilitas 0.05, dengan demikian Ho ditolak. Disimpulkan bahwa hasil tes sebelum diberikan perlakuan dan hasil tes setelah diberikan perlakuan hasilnya berbeda. Atau pembelajaran behasil untuk meningkatkan kemampuan peserta pembelajaran dengan online. Hasil 
pengujian penggunaan pembelajaran $M O O C$, tentunya didukung dengan kesadaran untuk memiliki kemampuan lebih dalam bidang pekerjaan yang sedang digeluti, kemandirian, kedisiplinan, dan keseriusan peserta dalam pelaksanaan proses pembelajaran online sehingga $M O O C$ ini memberikan bentuk lain untuk para pengelola perpustakaan kesempatan belajar sambil bekerj terutama dalam mempelajari dan memperoleh kemampuan literasi informasi.

\section{E. KESIMPULAN \\ REKOMENDASI}

DAN

Hasil penelaahan memberikan gambaran sebagai berikut. Pertama kesadaran personil perpustakaan sekolah untuk berperan aktif, partisipatif dan mandiri yang memiliki sebelumnya masih belum atau kurang memiliki literasi informasi dibangkitkan melalui partisipasi aktif mereka untuk mengembangkan diri melalui pembelajaran yang dikembangkan dalam riset ini. Kedua pengelolaan perpustakaan meningkat kemampuan literasi informasinya dengan mengikuti pembelajaran online dengan ruang ingkup yang dipelajari identifikasi kebutuhan informasi, pencarian informasi, kemasan informasi dan berbagi informasi juga dikembangkan melalui pemberian kerja praktek pada konsep dan sifat pembelajaran online.

Melalui bentuk MOOC maka diperoleh gambaran menyusun kemampuan literasi informasi dan paket informasi berbasis teknologi informasi dan komunikasi sebagai bentuk layanan dalam pembelajaran perpustakaan dilatih dalam kemasan akses online terbuka besar dan perlu dilakukan dan dikembangkan.

\section{F. REFERENSI}

Bruce, C. 1997. The seven faces of information literacy. Adelaide: Auslib Press.
Hobbs, R. 2011. "Empowering learnes with digital and media literacy" dalam Knowledge Quest vol. 39 no. 5, hal. $12-17$

IFLA. 2012. Moscow declaration on media and information literacy. [online]. Tersedia di: http://www.ifla.org/publications/mos cow-declaration-on-media-andinformation-literacy. Diakses tanggal 15 Mei 2013

Lankshear, C. \& Knobel, M. 2003. New Literacies : Everyday practices and classroom learning. Maidenhead : Open University Press.

Ong, W.J. 2002. Orality and literacy: the technologizing of the word. [online]. Tersedia di: http://monoskop.org/images/f/ff/

Ong,_Walter_J_-

_Orality_and_Literacy,_2nd_ed.pdf.

Diakses tanggal 11 nopember 2013

Pendit, Putu Laxman. 2012. Memahami literasi, informasi dan media. [online]. Tersedia di http:/www.lib.atmajaya.ac.id/default .aspx?tabID $=61 \& \mathrm{id}=185149 \& \mathrm{src}=\mathrm{k}$. Diakses tanggal 2 Januari 2013

Potter, W.J. 2010. "The State of media literacy" dalam Journal of Broadcasting \& Electronic Media, 54 (4), hal. 675-696.

UNESCO. 2011. Media and information literacy. [online]. Tersedia di: http://portal.unesco.org/ci/en/ev.phpURL_ID=15886\&URL_DO=DO_T OPIC\&URL_SECTION=201.html. Diakses tanggal 3 Desember 2012 